Chapter 8

\title{
Soil Salinization and Mitigation Measures in Land Reclamation Regions
}

\author{
Shiguo Xu, Yi Xu, Yanzhao Fu and Qi Wang
}

Additional information is available at the end of the chapter

http://dx.doi.org/10.5772/64720

\begin{abstract}
Soil salinization and underground structure erosion usually occur in land reclamation regions, especially under semi-humid climate that annual evaporation is larger than annual rainfall in Northern China. Based on investigations into the status and trends of land reclamation soil along the Bohai Rim, China, this chapter summarizes the evolution of groundwater system and soil environment and analyzes the main reasons contributing to these problems. Physical and mathematical models are established to simulate the mechanism of water-salt migration in land reclamation regions. Results show that evapotranspiration and groundwater discharge during wet seasons are the main driving forces of status of soil salinization. It was pointed out that the key to soil salinity control in the reclamation region was by utilizing rainwater and flood resources to build a longterm leaching mechanism. Meanwhile, in order to rebuild and maintain a healthy and stable ecosystem in the reclaimed areas, it is necessary to design the structure of soil layers in advance, enhance the salt leaching process and plant vegetation according to the local conditions.
\end{abstract}

Keywords: land reclamation, soil salinization, mechanism, environmental change, mitigation measures

\section{Introduction}

Coastal regions are identified as productive and sensitive ecosystems with abundant biodiversity. They are water bodies connected with both the land and the sea, and within which seawater mixes with inland freshwater discharge. Most of the megacities in the world are located in coastal regions, and more than 3 billion people which cover almost half of the world's population live along the coastline. The overloaded population increases the pressure on land 
resources. Along with the population growth, the utilization and development of coastal regions have increased in recent years and the changes in socioeconomic and environmental conditions are continuing. To cope with the expansion of urbanization, land reclamation was carried out.

Overloaded population and the needs for more agricultural land and for flood protection are the main reasons for the reclaiming. Land reclamation has expanded rapidly to adjust to economic development in coastal regions. It brings about more space, which alleviates the contradiction between supply and demand of land resources. Many coastal countries, including the developed ones such as the USA, Japan and Netherlands, have long histories of coastal reclamation. Netherlands, as an example, reclaimed about $7000 \mathrm{~km}^{2}$ from the sea and inland lakes since the $1300 \mathrm{~s}$, which covers up to $21 \%$ of the total land surface of the country [1]. Currently, these new formed lands have exceeded $140,000 \mathrm{~km}^{2}$ in the worldwide scale, and still increasing rapidly in some countries such as China [2].

However, reclamation disturbs the hydro-environment near the coast. It disrupts the watersalt movement and causes engineering, environmental and ecological problems. The quality of groundwater was affected by saline intrusion in the Netherlands [1]. Mangrove forest in China has been reported to be reduced by $53 \%$ than that in 1950s [3]. These degradations of marine habitats indicate that coastal ecosystem and hydrodynamic conditions are disturbed. The high density of salt in reclaimed regions exerts pressure on the local plants. If the salt pressure is weak, the injury to the plant could be recovered. The salinity in reclamation soil is $1-4 \%$ in $1 \mathrm{~m}^{3}$ which is much larger than the largest salinity that the most plants could bare $(0.3 \%)$. The mineralization ability in groundwater is more than $50 \mathrm{~g} / \mathrm{L}$. Only plant with shallow roots and high salt tolerance could survive in reclamation areas. Once the salt pressure exceeds the salt resistance of the plant, the life cycle of it will be destroyed and hence disturbs the whole ecosystem. Apart from this, social underground infrastructures are other victims of soil salinization. Seawater accelerates the corrosion rates of reinforced concretes and underground pipe networks which would threaten the security of coastal structures. Therefore, the understanding and mitigation of soil salinization in reclamation regions are important for coastal environmental protection.

Soil salinization is a tough problem for coastal environment and has drawn attention on a worldwide scale. Efforts have been made to study the mechanism and mitigation measures of it. Armstrong et al. [4] studied the seasonal variation in water and salt distribution in fields with both grassland and arable saline-sodic clay soils under temperate rain-fed conditions. Chen and Jiao [5] analyzed the groundwater chemistry in coastal aquifer and found that groundwater pumping was the reason for seawater intrusion. Iost et al. [6] found that reclamation influenced the local $\mathrm{pH}$ and carbonate content by decreasing calcium, magnesium and potassium while studying the initial pedogenesis of reclaimed saline marsh soils.

The objective of this chapter is to explore the mechanism of soil salinization in reclaimed coastal regions, especially that under semi-humid climate where evaporation is more than precipitation. In this chapter, the Bohai Rim, China, is selected as an example to study the water and salt migration in reclaimed soil. Physical model and numerical model are built for under- 
standing, quantifying and modelling the dynamic of seawater intrusion. Promising mitigation measures are also proposed.

\section{Investigation and analysis}

Surveying and analyzing are basic to study the physical and chemical properties of soil in reclamation regions. This chapter is based on the field surveys that were carried out along the coast line of the Bohai Sea, China. The surveys were taken on typical sea reclamation projects with similar climatic conditions.

\subsection{Study area}

The study area is located in the Bohai Rim, China (Figure 1), which has a semi-humid temperate monsoon climate with the average annual temperatures of $8.3-12.4^{\circ} \mathrm{C}$. The annual sunshine duration is $2500-2900 \mathrm{~h}$, and the annual total radiation is $5000-5800 \mathrm{MJ} / \mathrm{m}^{2}$. The annual precipitation is $612-640 \mathrm{~mm}$, which is concentrated in summer $(60-75 \%)$, and the annual evapotranspiration is $1300-1900 \mathrm{~mm}$. The ratio of precipitation and evaporation maintains 0.33 , which makes the water balance in the soils negative. The land reclamation projects were started during the 1980s. From 1996 to 2007, $551 \mathrm{~km}^{2}$ new lands were reclaimed and the annual reclamation area covers $80 \%$ of the country.

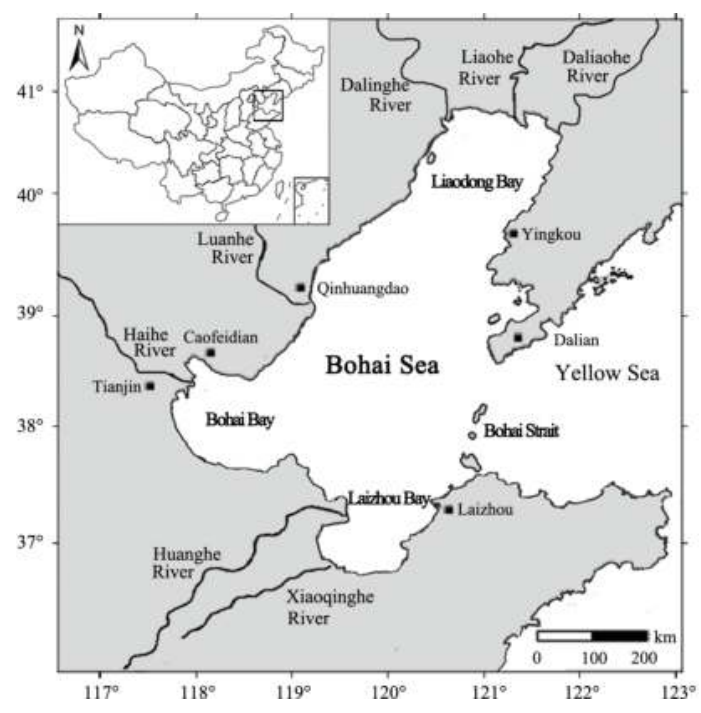

Figure 1. Location of the Bohai Rim.

The samplings of the research were carried out along the Bohai Rim. Samples of soil were collected from five main coastal cities where the reclamation projects were completed and the 
level of salt was stable. The reclaimed soil samples were collected using soil auger to a depth of $20 \mathrm{~cm}$, and control samples were collected in the natural coast nearby. Samples were then dried at $40{ }^{\circ} \mathrm{C}$ and sieved with $1 \mathrm{~mm}$ plastic sieve based on the standard for classification of soils (GBJ145-90). The physical and chemical properties of the soil were then analyzed in the laboratory.

\subsection{Salinization in land reclamation area}

Land formation in coastal area includes natural sedimentation and artificial landfills. Every year, the Yellow River brings about 1.5 billion tons of sediment to the estuary, two-thirds of which deposit in the delta. This area has the fastest land formation speed, where the shoreline is extended with an average distance of $1.8 \mathrm{~km}$ and formed $21.3 \mathrm{~km}^{2}$ tidelands each year. Artificial reclamation is often carried out on natural beaches using sea sand, mountain soils, minerals and construction waste, depending on the geological condition of the coast. Regions with hills and low mountains would use riprap filling method. While in river deltas, the method used is dredger filling (hydraulic filling). Although the soil structures are similar, there are differences in physical and chemical characteristics (Table 1).

\begin{tabular}{|c|c|c|c|c|c|c|c|}
\hline City & Soil type & $\begin{array}{l}\text { Water } \\
\text { content } \\
(\%)\end{array}$ & $\begin{array}{l}\text { Volumetric } \\
\text { weight } \\
\left(\mathrm{kN} / \mathrm{m}^{3}\right)\end{array}$ & $\begin{array}{l}\text { Specific } \\
\text { gravity }\end{array}$ & $\begin{array}{l}\text { Porosity } \\
(\%)\end{array}$ & $\begin{array}{l}\text { Water- } \\
\text { holding } \\
\text { capacity }(\%)\end{array}$ & $\begin{array}{l}\text { Permeability } \\
\text { coefficient (\%) }\end{array}$ \\
\hline \multirow[t]{2}{*}{ Tianjin } & Reclamation & 20.2 & 18.8 & 2.38 & 32.8 & 51.1 & $8.33 \times 10^{-7}$ \\
\hline & Planting & 3.9 & 14.2 & 2.22 & 41.1 & & \\
\hline \multirow[t]{2}{*}{ Caofeidian } & Reclamation & 3.4 & 13.9 & 2.61 & 45.8 & 22.9 & $2.75 \times 10^{-5}$ \\
\hline & Reclamation & 22.9 & 18.2 & 2.63 & 36 & 39.7 & $5.83 \times 10^{-6}$ \\
\hline \multirow[t]{2}{*}{ Laizhou } & Planting & 4.5 & 10.8 & 2.45 & 51.1 & & \\
\hline & Reclamation & 2.9 & 14.6 & 2.35 & 38.1 & 14.3 & $1.11 \times 10^{-5}$ \\
\hline \multirow[t]{2}{*}{ Yingkou } & Reclamation & 10.9 & 13.2 & 2.49 & 51.3 & 29.6 & $3.23 \times 10^{-5}$ \\
\hline & Hill & 26.7 & 16.7 & 2.41 & 44 & & \\
\hline \multirow[t]{3}{*}{ Dalian } & Reclamation & 27.2 & 16.6 & 2.39 & 43.8 & 23.6 & \\
\hline & Reclamation & 26.1 & 16.9 & 2.43 & 44.2 & 26.8 & $7.19 \times 10^{-4}$ \\
\hline & Reclamation & 19.2 & 17.3 & 2.45 & 35.4 & 21.1 & \\
\hline
\end{tabular}

Table 1. Location of the Bohai Rim.

Our research shows that Tianjin, Caofeidian and Laizhou are dredger filling reclamation regions, and Dalian and Yingkou are riprap filling land reclamation regions. The physical properties are analyzed and are listed in Table 1. The grain size of dredger filling soil is smaller than that of riprap filling soil. Seventy percent of the riprap filling soil is sand, which is also more than that of the soil from the hills where the riprap filling soil comes from. The density of riprap filling soil is smaller, while the porosity and the permeability coefficients are larger, which indicate the variation in salt water migration characteristics. The soil texture of dredger 
filling is heavier, and the original salinity is higher, which may cause salinization. Riprap fill, on the contrary, with greater thickness and larger bottom, has better connectivity to prevent salinization. The differences between riprap land reclamation and dredger fill reclamation are listed in Table 2. Large areas of these projects were built directly on former salt pans, which are the extreme examples of deposited salt density in sediment. This fact aggravates the surface salinization in the backfill area. The results show that the salt contents of the reclamation soil are consistent with the surface soil of salt pans nearby, which indicate the process of salt releasing from the sediment. This consistency tends to be clearer over time. The migration of water and salt in the backfill soil is controlled by the grain composition, which reflects the aquifer permeability and adsorbing capability of the soil particle. The salt in backfilling soil is accumulated in the surface layer. The groundwater was shallow buried $(1.5-2.5 \mathrm{~m})$ in the sampling sites which were all within the limit depth of phreatic evaporation. Therefore, the phreatic evaporation may be the main driving force of the salt accumulation in surface layer in reclamation regions. The main types of salt are $\mathrm{NaCl}$ and $\mathrm{CaCl}_{2}$ for dredger filling soil and $\mathrm{CaSO}_{4}$ for riprap filling soil.

\begin{tabular}{lll}
\hline & Dredger filling & Riprap filling \\
\hline Coast type & Muddy coast & Rocky coast \\
Geology condition & River deltas & Hills and low mountains \\
$\begin{array}{l}\text { Chemical character } \\
\text { of groundwater }\end{array}$ & Chloride & $\begin{array}{l}\text { Bicarbonate chloride, bicarbonate } \\
\text { chloride sulphate }\end{array}$ \\
Textural characteristics & Silt and clay & Brown soil \\
Reclamation scale & $>10 \mathrm{~km}^{2}$ & $<10 \mathrm{~km}^{2}$ \\
Cities & Tianjin, Caofeidian, Laizhou & Dalian, Yingkou \\
\hline
\end{tabular}

Table 2. Differences between dredger filling and riprap filling land reclamation.

\subsection{The movement of water and salt}

Rainfall, evaporation and runoff carry dissolved minerals and salts in continuous movement and form a uniform material flow. Different characteristics of salt migration occur in the different conditions of climate, soil and irrigation management, etc. In general, this process could be classified as salt leaching, salt accumulation and the release process of salts from sediment in the land reclamation regions.

\subsubsection{Salt leaching process}

Affected by the soil texture and structure, the impact depth of rainwater is limited, and the leaching effect in surface soil is stronger than that of the deep soil. The salinity peak declines with infiltration process until it disappears. The distribution of soil moisture in the $0-80 \mathrm{~cm}$ depth consists of a logarithmic curve in the absence of crops, and little effect was shown below $1.0 \mathrm{~m}$. A critical mutation in salinity variety exists around $40 \mathrm{~cm}$ depth, and a transition region appears from 50 to $70 \mathrm{~cm}$. Drizzle is not stronger enough to wash salt away, but it carries salt to the surface after rain stops. In agricultural area, large-scale irrigation contaminates fresh- 
water, and washes minerals and nitrate away, which may cause low soil permeability and nutrient content.

\subsubsection{Salt accumulation}

There has been a history of salt and water movement under evapotranspiration conditions. Fritton et al. [7] examined the differences of water-salt distributions under various evaporation intensities, and much research was subsequently focused on salt and water transport in soil [8]. A variety of formulas are widely used to calculate evaporation. However, studies on salt transport fell behind, relatively. Groundwater has significant effects on salt accumulation, although the drainage system is blocking it with flattening landform. The higher the salinity of groundwater, the more serious the salt accumulation. In the capillary rise zone, evaporation maintains a constant generally, but it decreases rapidly at the bottom of this zone and tends to zero, while the groundwater exceeds the impact depth. Throughout this process, the cumulative evaporation has a power function in relation to the diving depth [9]. It is easier to prevent salt upward and improve the leaching efficiency with a higher hydraulic gradient when the water table is deep. However, plants cannot grow up when the root zone lacks water. Zhang and Zhang [10] considered that the groundwater should be controlled at $0.7-0.8 \mathrm{~m}$ during the growth period, and fell to $1.2-1.4 \mathrm{~m}$ without crops.

In the high salinity environment, plants play an important role in salt regulation [11]. Plants may exacerbate salinization in sea reclamation areas during evapotranspiration, and the impact depth should be the sum of root depth and capillary rise height. The movements of salt and water become stable only when the groundwater is below the limited depth of phreatic evaporation.

\subsubsection{Salt releasing from sediment}

Sediment deposited on the seabed for years has high salinity of more than $10 \%$. When the environment changes to reclamation, salt in sediment will be gradually released. Environmental factors have obvious effects on the release of salt. For example, wind and temperature can promote this process, while the initial mineralization of groundwater will hinder it. In an acidic environment, the chemical properties maintain relative balances. Once these ions are in alkaline conditions, $\mathrm{Mg}^{2+}$ and $\mathrm{Ca}^{2+}$ would flocculate to deposition, which also accelerate the dispersion of magnesium and calcium.

Moreover, the environment of land reclamation areas is more complex than that of the natural coast. Groundwater replaces part of the saline water with the movement of fresh-salt water interface. Due to the restriction of upper soil, groundwater exchange is slow, and the accompanying removal of salt is too low. $\mathrm{Cl}^{-}$is a conservative ion excluded by soil colloids, which can migrate within groundwater freely, and of which the concentration is determined by the salinity of groundwater. In an open system, $\mathrm{Na}^{+}$is released from the sediment in exchanges for a continuous supply of $\mathrm{H}^{+}$. Meanwhile, $\mathrm{CO}_{2}$ released by plant roots generates excess $\mathrm{HCO}_{3}^{-}$ and $\mathrm{CO}_{3}^{2-}$, which may cause hydrolysis and acid erosion on rock and generate more dissolved 
salts. But in a closed system as reclamation region, the absence of $\mathrm{CO}_{2}$ decreases $\mathrm{HCO}_{3}^{-}$and $\mathrm{CO}_{3}^{2-}$ concentration. The bicarbonate-type groundwater transforms to chloride-type groundwater. Thus, the salinization will be intensified in land reclamation regions.

\section{The driving forces of salinization}

\subsection{Conceptual model}

The formation mechanisms of salinization are complicated for the multiple factors of water and salt movements. The sediment under the reclamation soil releases a large amount of salt, which was originally deposited in the oceanic environment over time. In a humid environment, with the upstream groundwater and rainfall supplement, the alkaline water in the reclamation soil is replaced by low-acid groundwater with higher dissolved oxygen. The fresh-salt water interface is pushed forward to the sea. However, under semi-humid climate where the evaporation rate is larger than the precipitation rate, with the effort of evapotranspiration, the salinity in reclamation soil increases, and thus, the fresh-salt water interface moves backwards to the continent (Figure 2).

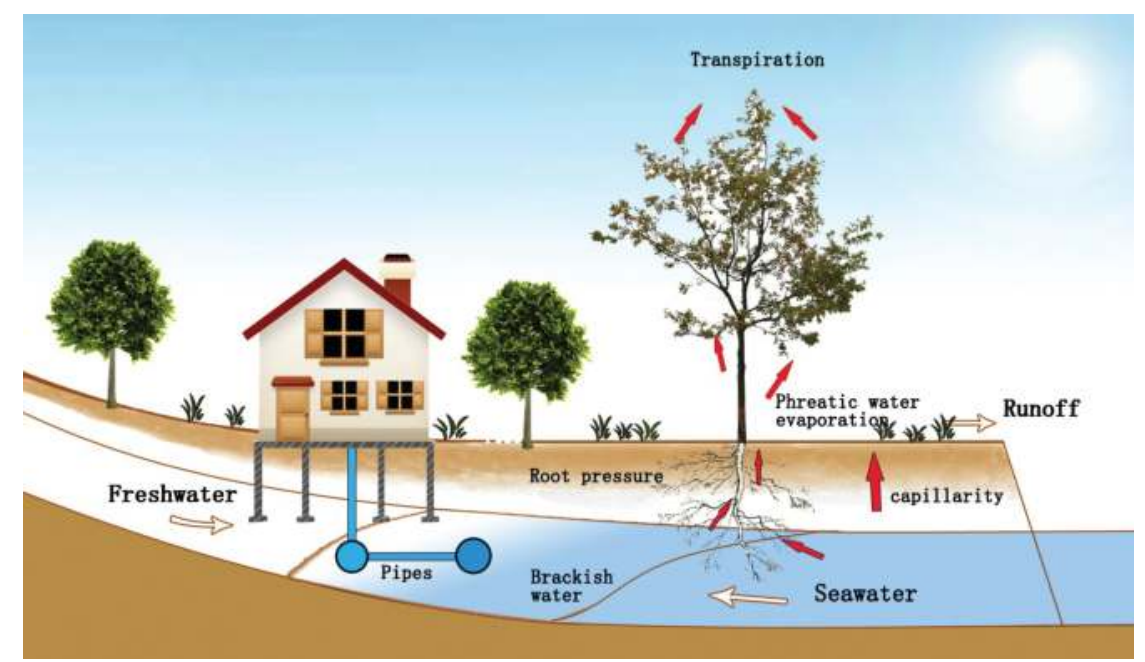

Figure 2. Concept map of water environment evolution in land reclamation regions.

\subsection{Physical model}

Semi-humid climate is an important incentive for coastal salinization. Taking Bohai Rim as an example, in recent years, global warming aggravates the evaporation process and salinization in sea reclamation region. Guan et al. [12] monitored the involvement of salinized coastal area 
around the Yellow River Estuary, and found that the saline land had expanded by $487.4 \mathrm{~km}^{2}$ over the last 15 years. To investigate the saline formation mechanism in compacted soil, we studied the salt transport processes under the joint action of phreatic water evaporation and lateral interflow.

\subsubsection{Experimental setup}

The experiment was carried out outdoor using the apparatus shown in Figure 3. Soil collected from the reclamation site in Dalian, China, was filled into a glass tank. The tank was $0.6 \mathrm{~m}$ high and was divided into three sections with two perforated plates which were the simulation of coastal constructions. The diameter of the holes was $1.0 \mathrm{~cm}$, and the interval between each hole was $5 \mathrm{~cm}$. In total, 25 monitor holes were reserved on the side of the tank as illustrated in Figure 3. Seawater collected from the reclamation site was poured initially into the tank at a depth of $10 \mathrm{~cm}$. The reclamation soil was then filled into the middle of the tank in layers. Each layer of the filling soil was $5 \mathrm{~cm}$. The soil tank was placed outside for 9 months with light-tight cover to prevent water loss. Then, fresh groundwater was poured into the Marriotte's bottle until the water level in the left section reached to $50 \mathrm{~cm}$. The purpose of this stage was to simulate the process of sideward flow in the soil. The $\mathrm{pH}$ value, electric conductivity and volumetric water content were measured during the experiment. Soil samples were also collected from the monitor hole at the end of each stage.

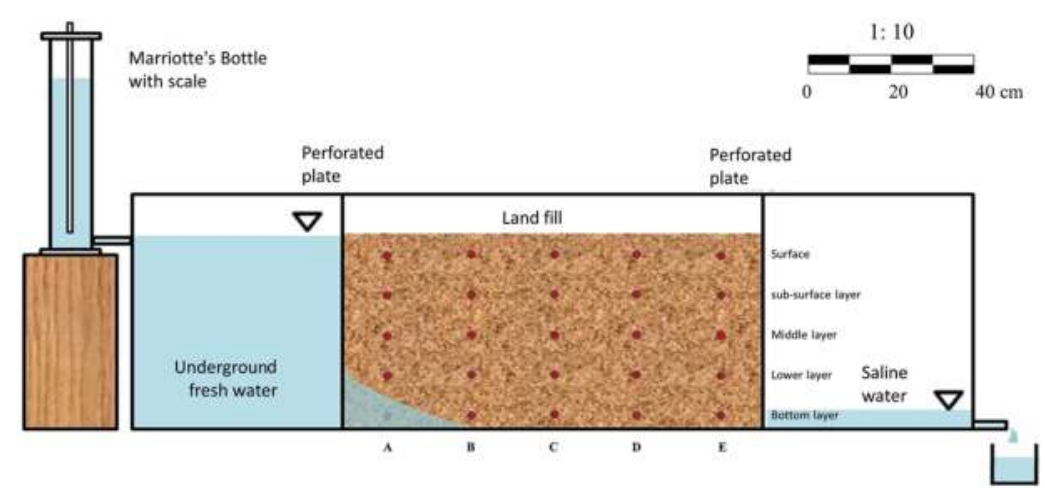

Figure 3. Testing apparatus.

\subsubsection{Phreatic evaporation stage}

The volumetric water content was dynamic during the experimental process (Figure 4). It first increased during the first month and reached a peak. Then, it decreased gradually until getting back to its initial state. In spatial scale, the water content was larger in bottom layer and smaller in surface layer. It was relatively stable in surface and subsurface layer horizontally. While under the middle layer, it was larger along the right side. These facts indicate that capillarity is the main driving force of the increase in water content. The soil matrix potential gradually 
decreased with the increase in water content. When the water content reached 3\%, the soil matrix potential meets the bottom and was stable ever since. The actual evaporation was little at first when the water content in the surface was low. With the increase in water content, the actual evaporation raised, which leads to the total loss of water content. The higher content along the right side was supplied by the seawater.

The total dissolved salt (TDS) in the soil increased during the evaporation process. It was larger in surface layer than that at the bottom and larger along the right side than the left. This indicates the salt accumulation with plenty supplement. The initial salt type of surface soil was $\mathrm{CaSO}_{4}$, and it gradually transited to $\mathrm{CaCl}_{2}$ and $\mathrm{NaCl}$ in the salt accumulation process. The salt type in the bottom layer was $\mathrm{NaCl} ; \mathrm{Mg}^{2+}$ presented tendency to dissolve in seawater and stayed in the right side of the tank. The $\mathrm{pH}$ value decreased on the left of the tank while increased on the right.
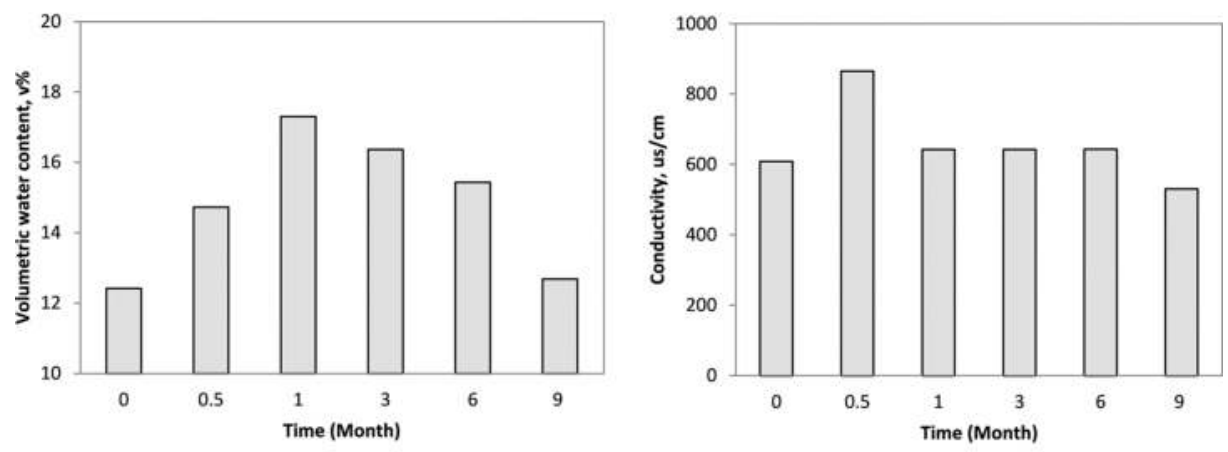

Figure 4. Variation in soil moisture and conductivity during the evaporation period.

\subsubsection{Seepage stage}

Under the seepage, the groundwater supply rate decreased with the increase in soil water content until $22 \mathrm{~h}$ later when there was water leaking out from the end of the tank (Figure 5(a)). The water content in the soil was stable since then. This dynamic was driven by the soil matrix potential. The potential-driven change rate (Figure 5(d)) decreased with the rise in the water table until the active water absorption stopped and a relatively free horizontal flow started, which leads to a stable velocity. The TDS of the soil was first increased because the crystal structure of salt in the soil was dissolved in the infilled groundwater (Figure 5(c)). The high TDS in the soil was carried out with the horizontal flow, and the TDS in the leaking water was high at first (Figure 5(b)). The time that TDS became stable was later than the flow rate indicates that the change in the salt front is later than in the wetting front.

The stable wetting front moves to the offshore, while the water table rises. Surface area above the free water is in the salt accumulation state, and the salt is mainly $\mathrm{CaCl}_{2}$ and $\mathrm{MgSO}_{4}$. The area below the free water surface is in the state of desalination, and the salt type is mainly 
$\mathrm{CaCl}_{2}$ and $\mathrm{NaCl}$. Water and salt movement will change the $\mathrm{pH}$ value of the soil environment; the $\mathrm{pH}$ value will increase with the increase in salt content first decreased slightly after the rise.
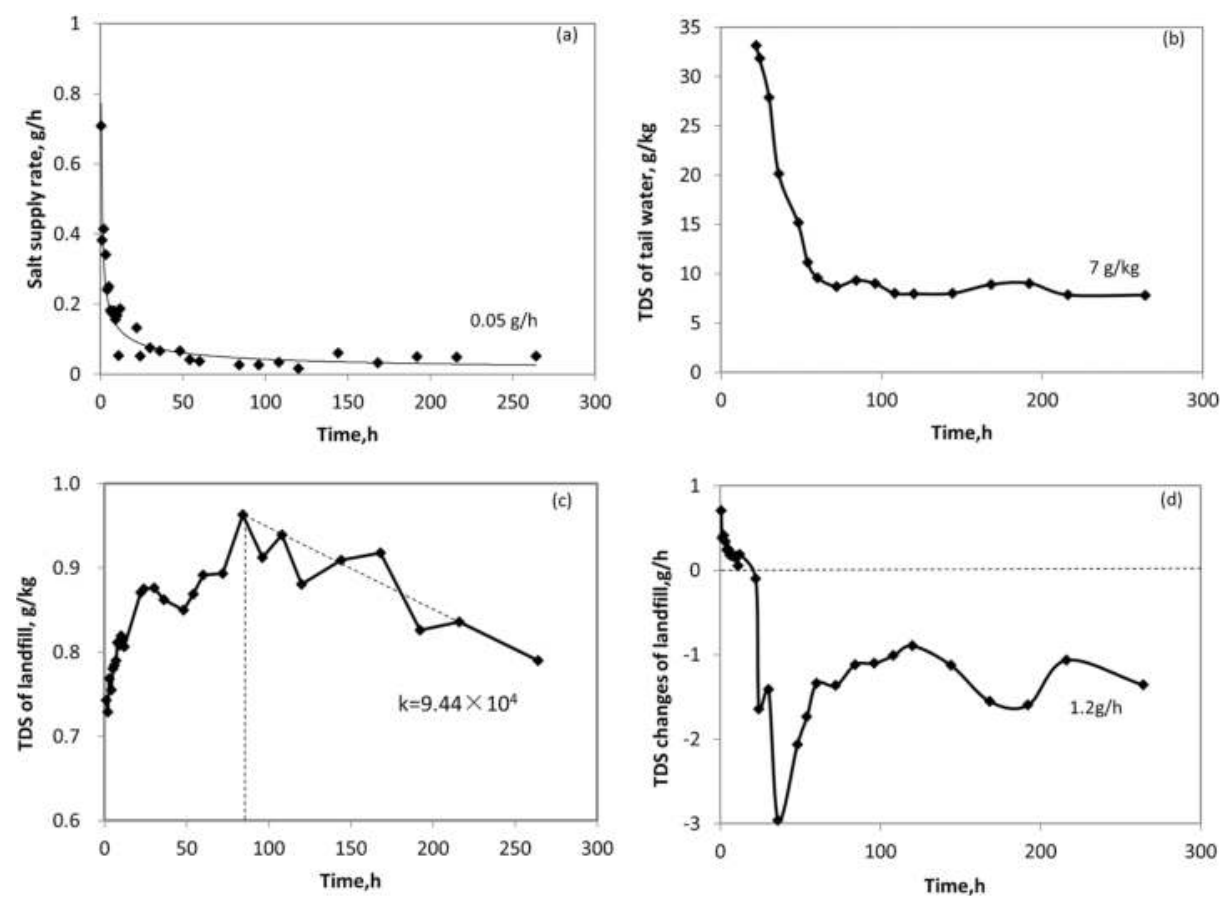

Figure 5. Variation in soil moisture, water supply and permeability.

\subsubsection{Salt migration in land reclamation regions}

In semi-humid coastal region, the water content in surface layer and water table of groundwater are the main factors of salt accumulation due to low precipitation rate but high evaporation. During the dry seasons, low groundwater supply rate from the continent pushes the freshwater and seawater interface upwards to the continent. When the water table meets the phreatic evaporation depth, $\mathrm{Cl}^{-}$moves upwards and the $\mathrm{CaSO}_{4}$ in surface layer is replaced by $\mathrm{CaCl}_{2}$. With the consistent supply of $\mathrm{Na}^{+}$and $\mathrm{Mg}^{2+}$, most of the salt in the soil is replaced by $\mathrm{NaCl}$. In wet seasons, the groundwater water table rises and the wetting front moves downwards to the sea with salt front following. In reclaimed regions where there are obstacles (clay or coastal constructions), the water table would be raised. Salt in groundwater would also be raised with the water table which would then accumulate in the surface layer. $\mathrm{CaCl}_{2}$ and $\mathrm{MgSO}_{4}$ accumulated in the surface layer near the obstacles and $\mathrm{NaCl}$ accumulated at the bottom. Therefore, in terrestrial groundwater recharge conditions, land reclamation area of 
salinization prevention and control work should focus on underground baffle layer or foundation of a building with a relatively dense region.

\subsection{Numerical model}

Apart from the physical model, FEFLOW was employed to simulate the migration of water and salt within a unit of a typical land reclamation project. The combined effects of two driving factors, phreatic evaporation and rainfall infiltration, were selected to reveal the migration process in the simulation. Then, the effects of salinity suppression of different measures for rainwater utilization were analyzed.

\subsubsection{Model domain description}

Due to lack of geological survey data, long sequence groundwater level and solute concentration monitoring data of practical projects, the model domain was an imaginary land reclamation project which was based on Lingshui Bay land reclamation project in Dalian city, China, and several engineering examples in North China. The theoretical model (Figure 6) was designed to explore the mechanism of soil water and salt transport in reclamation areas in the north region of China and provide trend analysis results for practical projects.

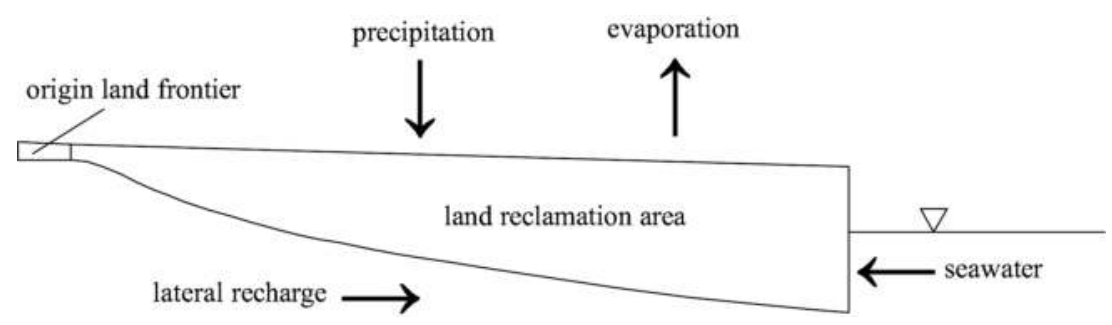

Figure 6. The schematic diagram of model domain.

The left border in Figure 6 is the land frontier before the project implementation, and the right border is the new land frontier. Considering that the extended distance from landside to the sea was less than $1 \mathrm{~km}$ in general cases, the extended distance was set to be $1 \mathrm{~km}$. The surface grade was $3 \%$, and the lateral cofferdam was $5.5 \mathrm{~m}$ in accordance with land reclamation engineering specifications. The structure of earth fill is designed according to Lingshui Bay land reclamation project.

\subsubsection{About Feflow}

FEFLOW is a finite element-based groundwater simulation system. It is considered to be a comprehensive, well-tested and reliable program for the simulation of flow, mass and heat transport processed in porous media. FEFLOW provides data interfaces for geographic information system and can generate spatial finite element grids automatically. The system is equipped with fast and accurate numeric algorithms to control and optimize the solution 
procedure, and advanced visual figures are embodied in output results. FEFLOW is used to compute groundwater flow dynamics in unconfined and confined aquifers and multiple free water surface(s); describe the spatial and temporal distribution of contaminants and/or temperature fields; estimate the duration and travel time of contaminants in groundwater; study saltwater intrusion and so on.

\subsubsection{Mass transport model building}

A two-dimensional coupled groundwater flow and mass transport model in vertical section was established (Figure 7). The left border was generalized as the boundary of known flow, and the groundwater flow was determined by the measured value in Lingshui Bay land reclamation project. The right border was defined as the boundary of known water level. The model contained five layers in vertical direction according to the soil layer. The top layer was planting soil layer. The second, third and fourth layers were compacted fill layer. The bottom layer was natural sediments with weak permeability. The free water surface of the unconfined aquifer was the upper boundary, and the bottom of the aquifer was impervious boundary.

Groundwater recharge in model area mainly included precipitation infiltration recharge and lateral recharge, and evaporation and runoff into the sea is the main way of groundwater discharge. Precipitation and evaporation data were referred to meteorological stations near Lingshui Bay. Spring and autumn were the evaporation periods. The precipitation was concentrated in summer, so summer was the leaching period. There was little rainfall from winter to early spring, and the evaporation was weak due to low temperature. Evaporation capacity was much higher than rainfall capacity, and the ratio was about 2.3, which meant that the driving effect by phreatic water evaporation was strong. Salt would accumulate in shallow ground in the process of migration, ultimately resulting in soil salinization. Boundary conditions including lateral runoff, sea level and chloride concentration, parameters such as groundwater chloride ion content, precipitation recharge coefficient, specific yield and porosity were assigned according to the Lingshui Bay land reclamation project. Initial groundwater level was $0.7 \mathrm{~m}$, which was equal to local capillary height, and initial groundwater chloride content was equal to that in seawater. Initial dispersion coefficient values were referred to previous experience and revised repeatedly in the simulation process. The simulation period was from spring and lasted for 5 years (1825d).

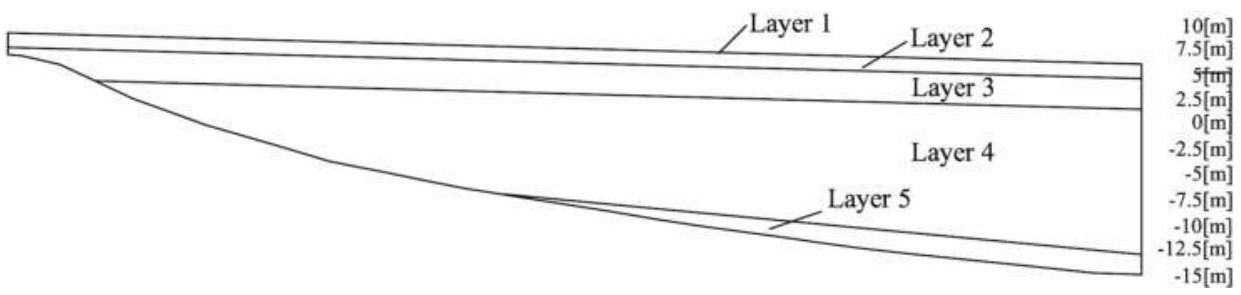

Figure 7. Soil layers of the model. 


\subsubsection{Simulation results and analysis}

\subsubsection{Groundwater level}

After the model runs for 5 years (the fifth year after the completion of land reclamation project), the groundwater level is shown in Figure 8. Because of the construction of land reclamation project, the discharge outlet is cut off. Groundwater from the origin land frontier and the sea enters into the fill, causing a gradual increase in groundwater level in this area. Groundwater level in the model domain after model runs for 1, 3 and 5 years is analyzed. It indicates that groundwater level becomes stable over time. Groundwater table near the original land frontier is higher and gets closer to the limit-evaporable depth of groundwater, in which condition salt can migrate to shallow ground. In spring and summer, the evaporation is intensive, while there is no adequate supply; so groundwater table is relatively low.

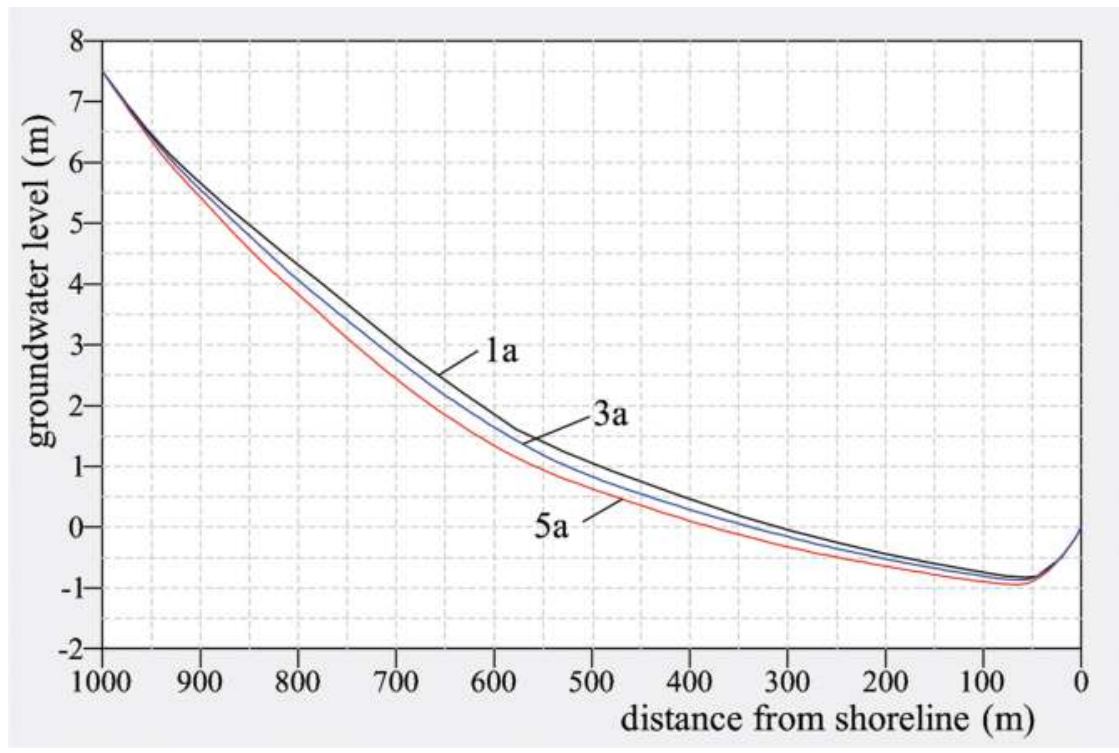

Figure 8. Groundwater level in the simulation area.

\subsubsection{Chloride concentration}

Groundwater chloride concentration after the model runs for 1, 3 and 5 years in model area is seen in Figure 9. As groundwater from the original land frontier enters into the reclamation area and precipitation infiltration recharge, groundwater salt within the capillary height is diluted. However, chloride concentration is still in high level. Groundwater chloride concentration near the sea is much higher. In spring and autumn, chloride concentration is over $14000 \mathrm{mg} / \mathrm{L}$ where groundwater is lower than $1 \mathrm{~m}$ due to insufficient lateral supply. On the whole, groundwater chloride concentration gets higher from land to the sea. Therefore, 
countermeasures such as recharge wells are suggested to promote salt water discharge into the sea and inhibit seawater intrusion.

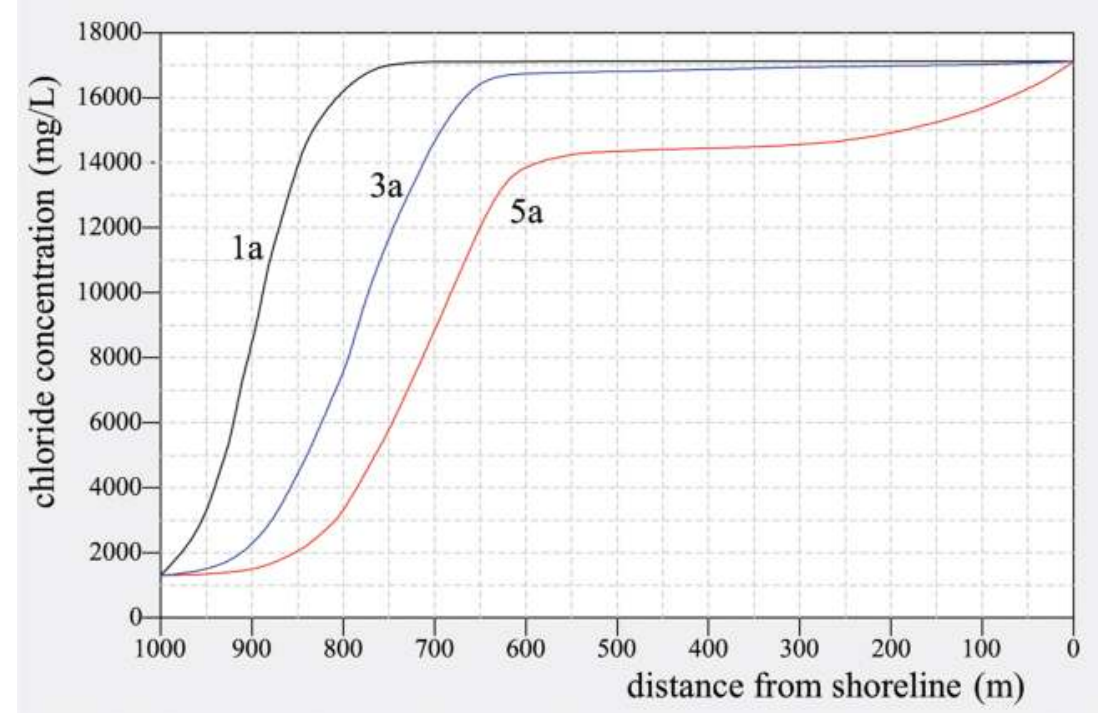

Figure 9. Groundwater chloride concentration in model area.

\section{Mitigation methods}

\subsection{Soil structure reforms}

Soil is an important medium for salt and water transport. Its structure directly determines the hydraulic conductivity. The capillary effect is the major force driving water rise, whether the water table located on the capillary rise zone has an obvious effect on the amount of evaporation. Once the capillary is destroyed if a multilayered structure is designed in the land reclamation zone, the salt accumulation process will be prevented. Therefore, it is meaningful to design multilevel backfilling technology based on the mechanism of salt movement in the reclamation area. Hornbuckle et al. [13] introduced that multilevel drainage system could provide faster leaching rate in the root zone, without increase in salt loads.

\subsection{Sediment property modifications}

In the reclamation regions, coastal sediment is often used to improve the physical and chemical properties of soil and construct grassy areas, because the organic matter content in offshore and river areas is high and acidic. Containing abundant microbes, sediment can increase the number of microorganisms and soil microbial population structure and improve the fertility 
of soil enzyme activity and content of humus. However, coastal sediment is rich in salt and heavy metal pollutants, and the soil particle size is small, which is easy to harden after dehydration. Therefore, coastal sediment needs to be modified before its application on the reclamation soil.

\subsection{Rainwater utilization and desalination}

Phreatic water is a sensitive element of the environment. Due to the shallow depth and high salinity of groundwater, efficient desalination system for reclaimed land is necessary. Many scholars used drainage system in salt elimination, but well-canal combined method is the main desalination technology recently [14, 15]. For coastal saline soil, desalination technology based on hydraulics was proposed. The freshwater resources in semi-humid regions are limited, and the groundwater discharge is not enough to push the fresh-salt water downwards to the sea. In the sea reclamation region, rainwater is infiltrated into soil by engineering measures, which could remedy the seasonal distribution defect of precipitation and adjust the groundwater environment. For example, rainwater is collected to construct the layer of salt leaching, and the soil drainage system is improved to control the underground water level and the salt content. Both methods above prove that it is feasible to build the long-term desalination mechanism of rain. Xu et al. [16] found that rainwater infiltration through pervious pavements can effectively resist seawater intrusion and the interface of fresh-salt water is pushed to the coastline. It is helpful to combat the salinization using rainwater infilling method in urban area.

\subsection{Conservation tillage}

Although the parent material under the reclaimed soil is complicated, the clay layer contains little organic matter due to lacking of supply. Soil and water loss will damage ecological resources and lead to ecological degradation. Conservation tillage has been used in the northeast of China to protect soil and water resources by preventing soil erosion. For example, straw return is an efficient strategy to enhance soil fertility, which provides a buffer for raindrops to transfer energy and promotes the infiltration rates of salt leaching. In the long term, conservation tillage will be an efficient method for saline soil restoration and ecosystem restoration.

\section{Conclusion}

Economic benefits could not justify the impacts of reclaiming land on coastal ecological degradation. Salinization is one of the major problems. Mitigation measures have been proposed, and some have successful achievements. However, most of these methods are based on experiences, and lack of theoretical bases. The effects of the mitigation measures on shortterm and long-term monitoring are still necessary in the complicated land reclamation regions to get full understanding of the mechanism of soil salinization.

Research including field investigation, modelling and analysis was carried out in land reclamation areas. Results show that under semi-humid climate, the salinity problem in 
reclaimed land is severe. Driven by climate, vegetation and upstream freshwater supply, the migration of water and salt is dynamic. The processes could be classified as salt leaching, salt accumulation and the release process of salts from sediment. Measures should be taken to prevent the soil salinization. Major ways include rainwater utilization, conservation tillage, soil structure reform, desalination and sediment property modifying.

\section{Acknowledgements}

This research is supported by the project (51279022) of the National Nature Science Foundation of China.

\section{Author details}

Shiguo $\mathrm{Xu}^{1^{*}}$, Yi $\mathrm{Xu}^{1,2}$, Yanzhao $\mathrm{Fu}^{1}$ and Qi Wang ${ }^{1}$

*Address all correspondence to: yzfu@mail.dlut.edu.cn

1 Institute of Water and Environment Research, Dalian University of Technology, Dalian, China

2 Shenyang Academy of Environmental Sciences, Shenyang, China

\section{References}

[1] Stuyfzand, P.J. The impact of land reclamation on groundwater quality and future drinking water supply in the Netherlands. Water Science and Technology. 1995;31(8): 47-57. doi:10.1016/0273-1223(95)00356-r

[2] Xu, Y., Xu, S.G., and Xu, X.Z. Analysis of water and salt migration in sea reclamation regions under a semi-arid climate. In: XXV Iugg General Assembly; 28th June-7th July 2011; Melbourne, Australia. IAHS-AISH publication; 2011. p. 213-219.

[3] Xu, S.G. and $\mathrm{Xu}, \mathrm{Y}$. Review on water environment evolution and strategy after land reclamation. Advances in Water Science. 2013;24(1):138-145. doi:10.14042/j.cnki. 32.1309.2013.01.016 (in Chinese)

[4] Armstrong, A., D. Rycroft, and T. Tanton. Seasonal movement of salts in naturally structured saline-sodic clay soils. Agricultural Water Management. 1996;32(1):15-27. doi:10.1016/s0378-3774(96)01262-0. 
[5] Chen, K. and J.J. Jiao. Seawater intrusion and aquifer freshening near reclaimed coastal area of Shenzhen. Water Science and Technology: Water Supply. 2007;7(2):137-145. doi: 10.2166/ws.2007.048.

[6] Iost, S., D. Landgraf, and F. Makeschin. Chemical soil properties of reclaimed marsh soil from Zhejiang Province PR China. Geoderma. 2007;142(3):245-250. doi:10.1016/ j.geoderma..08.001.

[7] Fritton, D. D., Kirkham, and R. Shaw. Soil water and chloride redistribution under various evaporation potentials. Soil Science Society of America Journal. 1967;31(5):599603. doi:10.2136/sssaj1967.03615995003100050002x

[8] Nakagawa, K., et al. Modelling reactive solute transport from groundwater to soil surface under evaporation. Hydrological Processes. 2010;24(5):608-617. doi:10.1002/ hyp.7555.

[9] Jia, Y.M. Experimental Study of Phreatic Evaporation at Different Depth of Groundwater Table. Journal of Irrigation and Drainage. 2008;27(6):021. doi:10.13522/ j.cnki.ggps .2008.06.021 (in Chinese)

[10] Zhang, W.Z. and Zhang, Y.F. Examinations of balancing water and salt in irrigated districts and control of soil saline and alkaline. China Water Resources. 2003;16:24-30. doi:10.3969/j.issn.1000-1123.2003.16.005.

[11] Cui, Y.H., Zhang, R.M., et. al. Researches on the relationship of evapotanspiration and salinity. Inner Mongolia Science Technology and Economy. 2002;5:18-20. doi:10.3969/ j.issn.1007-6921.2002.05.006.

[12] Guan, Y.X., Liu, G.H., Wang, J.F., Regionalization of salt-affected land for amelioration in the Yellow River Delta based on GIS. Acta Geographica Sinica. 2001;56(2):205-212. doi:10.3321/j.issn:0375-5444.2001.02.008.

[13] Hornbuckle, J.W., E.W. Christen, and R.D. Faulkner. Evaluating a multi-level subsurface drainage system for improved drainage water quality. Agricultural Water Management. 2007;89(3):208-216. doi:10.1016/j.agwat.2007.01.004.

[14] Heydari, N., A.D. Gupta, and R. Loof. Salinity and sodicity influences on infiltration during surge flow irrigation. Irrigation Science. 2001;20(4):165-173. doi:10.1007/ s002710100043.

[15] Bakker, D., et al. Salinity dynamics and the potential for improvement of waterlogged and saline land in a Mediterranean climate using permanent raised beds. Soil and Tillage Research. 2010;110(1):8-24. doi:10.1016/j.still.2010.06.004.

[16] Xu, S.G., Gao, J.H., and Chang, N.B. Hydrological and environmental modeling analyses of pervious pavement impact in a coastal city. In: Book chapter, Chang, N.B. editor. Effects of Urbanization on Groundwater: An Engineering Case-based Approach for Sustainable Development. Reston: American Society of Civil Engineers (ASCE); 2010. p. 367-388. DOI:061/9780784410783.ch14. 
